\title{
Mutu Glikemik Kue Bingke Variasi Umbi di Kota Pontianak
}

\section{Nutritional Quality of Bingke Cakes with Variations of Tubers in Pontianak City}

\author{
Oke Anandika Lestari*, Yohana Sutiknyawati Kusuma Dewi, dan Mardiana Putri \\ Fakultas Pertanian, Universitas Tanjungpura, Pontianak
}

\begin{abstract}
This study aims to obtain the number of consumption portions $(g)$ of sweet potato and potato variations of bingke which have a low glycemic load $(G L)$ value. GL is the glycemic load of a food after being consumed at a certain amount. The GL value is determined from the glycemic index (GI) value and the carbohydrate content per serving. The glycemic index is food categorization (low, medium, high) based on its speed in increasing glucose levels in the blood. Diabetes mellitus sufferers are advised to pay attention to food consumption based on food categories, especially those with low GI values. However, the amount consumed will also affect the increase in glucose levels in the blood, this is reflected in the GL value. This study was conducted using 10 healthy respondents aged 22 years, normal body mass index (BMI), normal fasting blood sugar, and not smoking. The results obtained by the variety of tuber bingke cakes (sweet potatoes and potatoes) have a high GI value category with a low GL consumption portion of $120 \mathrm{~g}$ (2 pieces). As a complement to the data, a survey was also carried out on 100 random respondents which showed that the type of bingke cake the variety of sweet potato was preferred and the number of consumption of one meal of bingke cake was two pieces.This amount can be recommended to be the amount of one consumption (one meal portion).
\end{abstract}

Keywords: sweet potato, potato, glycemic index (GI), glycemic load (GL)

\begin{abstract}
Abstrak. Penelitian ini bertujuan untuk mendapatkan jumlah porsi konsumsi (g) kue bingke variasi ubi jalar dan kentang yang memiliki nilai beban glikemik (BG) rendah. BG merupakan beban glikemik suatu pangan setelah dikonsumsi pada jumlah tertentu. Nilai BG ditentukan dari nilai indeks glikemik (IG) dan kadar karbohidrat per porsi. Indeks glikemik merupakan pengkatagorian pangan (rendah, sedang, tinggi) berdasarkan kecepatannya dalam meningkatkan kadar glukosa dalam darah. Penderita diabetes melitus disarankan untuk memperhatikan konsumsi pangan berdasarkan katagori pangan, terutama disarankan yang memiliki nilai IG rendah. Akan tetapi jumah yang dikonsumsi juga akan mempengaruhi peningkatan kadar glukosa dalam darah, hal tersebut tergambarkan dalam nilai BG. Penelitian ini dilakukan dengan menggunakan 10 orang responden sehat dengan umur 22 tahun, indeks masa tubuh (IMT) normal, gula darah puasa normal, dan tidak merokok. Hasil yang diperoleh kue bingke variasi umbi (ubi jalar dan kentang) memiliki katagori nilai IG tinggi dengan porsi konsumsi BG rendah sebanyak $120 \mathrm{~g}$ ( 2 potong). Sebagai pelengkap data juga dilakukan survei pada 100 responden secara acak yang menunjukkan jenis kue bingke variasi ubi jalar lebih disukai dan jumlah konsumsi sekali makan kue bingke adalah dua potong. Makanan dengan IG yang tinggi bukan berarti tidak boleh dikonsumsi, akan tetapi pengaturan lebih bijak dapat dilakukan dalam segi jumlah sekali makan (porsi).
\end{abstract}

Kata Kunci: ubi jalar, kentang, indeks glikemik (IG), beban glikemik (BG)

Aplikasi Praktis: Penelitian ini memberikan informasi jumlah konsumsi sekali makan kue bingke
variasi ubi jalar dan kentang berdasarkan katagori beban glikemik rendah. Hasil penelitian dapat menjadi
rujukan dalam melengkapi informasi gizi kue bingke, terutama variasi ubi jalar dan kentang.

\section{PENDAHULUAN}

Kue bingke termasuk dalam kue basah, sesuai dengan karakteristik kue basah menurut (Putri dan Syarif 2019) memiliki tekstur empuk, lembut, dan basah, serta umumnya memiliki umur simpan yang singkat. Selain itu kue bingke memiliki bentuk yang khas yaitu seperti bunga dengan enam (6) kelopak sehingga, umumnya masyarakat membuat potongan antar kelopak sebagai penyajian. Bahan baku utama kue bingke terdiri dari adonan tepung terigu, telur, gula, dan

Korespondensi: oke.anandika@gmail.com santan (Panjaitan et al. 2014). Bahan baku kue bingke saat ini telah dimodifikasi dengan menggunakan bahan baku lokal, seperti tapai dan kentang, tepung kacang hijau (Lestari et al. 2017), ubi jalar dan kentang (Putri et al. 2019), serta tepung garut (Ilmannafian et al. 2018). Variasi bahan baku lokal yang ditambahkan pada kue bingke di kota Pontianak diantaranya adalah penggunaan umbi, yaitu ubi jalar dan kentang.

Modifikasi bahan baku lokal (umbi) secara tidak langsung menambahkan komposisi karbohidrat pada kue bingke. Karakteristik rasa manis dan penambahan karbohidrat pada kue bingke memiliki potensi untuk meningkatkan kadar glukosa darah setelah dikonsumsi. Pening- 
katan kadar glukosa darah dengan cepat tidak disarankan bagi penderita diabetes melitus (DM) karena penderita DM memiliki gangguan metabolik yang menyebabkan terjadinya hiperglikemik (tingginya kadar glukosa darah). Pengontrolan hal tersebut dilakukan dengan pengelompokkan makanan berdasarkan katagori indeks glikemik (IG), yaitu rendah (<55), sedang (55-70), tinggi $(>70)$. Semakin tinggi nilai indek glikemik menggambarkan makanan tersebut mudah dicerna sehingga cepat meningkatkan kadar glukosa dalam darah, kondisi tersebut tidak diharapkan bagi penderita DM. Konsumsi makanan dengan IG rendah dapat mengurangi resiko kejadian diabetes melitus tipe 2 sebesar $36 \%$ pada orang beresiko tinggi (Chiasson et al. 2002). Penelitian menggunakan pasien DM menunjukkan penurunan kadar HbA1c yang signifikan pada pemberian makanan rendah IG (Thomas dan Elliott 2010), sedangkan pemberian makanan dengan IG tinggi secara in vivo menunjukkan adanya kerusakan pada sel beta pankreas (Pawlak et al. 2004).

Setelah mengetahui IG makanan tersebut, dilanjutkan dengan menentukan nilai beban glikemik (BG) sebagai kontrol jumlah konsumsi. Beban glikemik mengelompokkan makanan dengan memperhitungkan nilai IG dan jumlah karbohidrat per porsi, menurut (Powell et al. 2002) yaitu rendah (<10), sedang (11-19), dan tinggi (>20). Pola konsumsi dengan IG dan BG rendah tidak hanya bermanfaat bagi penderita DM, tetapi juga dapat mencegah penyakit kardiovaskular. Indeks glikemik dapat menjadi faktor resiko kuat DM terutama tipe 2, sedangkan BG untuk penyakit jantung (Agustin et al. 2015).

Aplikasi penambahan bahan baku berbasis karbohidrat menjadikan kue bingke menarik untuk dilakukan pengukuran respon konsumsinya terhadap perubahan kadar glukosa darah. Hal tersebut belum pernah dilaporkan sebelumnya. Penelitian terdahulu belum ada yang memberikan informasi terkait porsi konsumsi kue bingke berdasarkan nilai BG yang rendah. Oleh sebab itu dalam penelitian ini bertujuan untuk mendapatkan jumlah porsi konsumsi (g) kue bingke variasi ubi jalar dan kentang di kota Pontianak yang memiliki nilai beban glikemik (BG) rendah.

\section{BAHAN DAN METODE}

\section{Bahan}

Bahan utama yang digunakan dalam penelitian ini adalah kue bingke variasi ubi jalar dan kentang yang diperoleh dari toko kue bingke di kota Pontianak. Bahan lainnya adalah kit glukosa (merk Accu-Chek), glukosa (merk Glucolin), dan air mineral. Alat yang digunakan dalam penelitian ini adalah glukometer merk AccuChek.

Penelitian ini telah memiliki keterangan lolos kaji etik (Ethical-Clearance) dengan nomor 650/UN2 2.9/ DL/2018. Penelitian dilakukan dengan menggunakan responden orang sehat berdasarkan data indeks masa

tubuh (IMT dalam $\mathrm{kg} / \mathrm{m}^{2}$ ), kadar glukosa darah puasa (GDP), dan tidak merokok.

\section{Penentuan jumlah sampel}

Sampel yang digunakan adalah kue bingke dari salah satu toko kue bingke di kota Pontianak (Gambar 1). Penentuan tersebut berdasarkan hasil penelitian terdahulu, bahwa bingke variasi ubi jalar dan kentang dari toko tersebut adalah yang paling disukai (Putri et al. 2019). Selain itu telah diketahui komposisi gizi yang terkandung pada kedua variasi kue bingke tersebut yang ditampilkan pada Tabel 1. Berdasarkan Tabel 1 tersebut diketahui kandungan karbohidrat kue bingke kedua variasi sama yaitu 8.73 per 100 g. Berdasarkan pertimbangan kewajaran porsi konsumsi maka ditentukan jumlah sampel berbasis kandungan karbohidrat sebanyak $25 \mathrm{~g}$ (umumnya 50g), hal tersebut juga dilakukan pada pengukuran IG pada sampel sayuran dan buah (Fatema et al. 2011). Jumlah sampel yang diberikan dihitung dengan membagi $25 \mathrm{~g}$ dengan karbohidrat per $100 \mathrm{~g}$ (BPOM 2011).

Tabel 1. Komposisi gizi kue bingke variasi ubi jalar dan kentang

\begin{tabular}{lcc}
\hline Analisis Proksimat & Bingke Ubi Jalar & Bingke Kentang \\
\hline Kadar air & 64.64 & 63.75 \\
Kadar abu & 0.76 & 0.62 \\
Kadar lemak & 21.86 & 22.07 \\
Kadar protein & 4.02 & 4.82 \\
Kadar karbohidrat & 8.73 & 8.73
\end{tabular}

Sumber: (Putri et al. 2019)

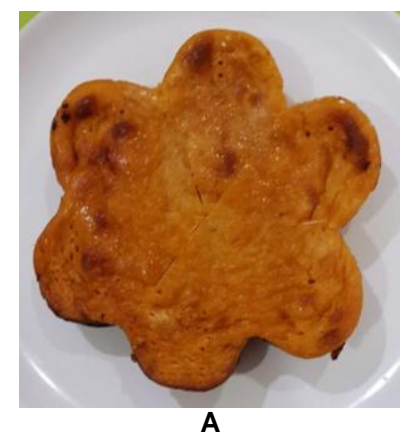

Gambar 1. Kue bingke ubi jalar kentang (b)

\section{Survei konsumsi}

Survei konsumsi ini dilakukan dengan teknik wawancara singkat pada 100 orang di lingkungan universitas Tanjungpura Fakultas Pertanian secara acak untuk mendapatkan jenis variasi kue bingke ubi jalar atau kentang yang suka dikonsumsi dan jumlah porsi sekali makan kue bingke yang biasa dikonsumsi. Data dikalkulasi dalam bentuk persentase.

\section{Pengukuran indeks glikemik (IG)}

Pengukuran indeks glikemik dilakukan dengan responden sehat sebanyak 10 orang. Responden diseleksi berdasarkan umur (22-21), IMT normal (18.524.9), gula darah puasa (GDP) normal (70-110 mg/dl), 
dan tidak merokok. Pengukuran nilai indeks glikemik dilakukan dengan mempuasakan responden selama 10 jam (bebas minum air putih), setelah diberikan konsumsi yang seragam, serta disarankan tidak melakukan aktivitas berat. Pengukuran kadar glukosa puasa dilakukan sembelum diberikan sampel (data glukosa darah menit ke-0). Responden diberikan sampel glukosa sebanyak 25 g dalam $100 \mathrm{~mL}$ air mineral, kemudian waktu setelah mengonsumsi dicatat sebagai patokan 30 menit berikutnya sebagai data glukosa darah menit ke-30. Pengukran kadar glukosa dilakukan hingga menit ke-120 setiap 30 menit. Hasil pengukuran kadar glukosa darah di plot pada grafik dengan patokan semua data di kurangi dengan kadar glukosa darah menit ke-0, sehingga pada menit ke-0 nilai gula darah puasa pada grafik adalah nol (0). Grafik di plot dengan sumbu x waktu (menit), dan sumbu y kadar glukosa darah $(\mathrm{mg} / \mathrm{dl})$. Indeks glikemik dihitung dengan rumus 2 berdasarkan luar kurva diatas sumbu y bernilai nol (0) (BPOM 2011). Hal yang sama dilakukan pada sampel kue bingke variasi ubi jalar dan kentang yang dilakukan pada hari yang berbeda (jarak pengambilan data antar sampel tidak lebih dari 7 hari). Nilai IG dihitung dengan rumus sebagai berikut (BPOM 2011):

$$
I G=\frac{\text { Luas kurva sampel }}{\text { Luas kurva standar (glukosa) }} \times 100
$$

\section{Beban glikemik (BG)}

Porsi kue bingke dibuat dalam kelipatan $60 \mathrm{~g}$ berdasarkan berat setiap kelopak (umumnya potongan kue bingke per kelopak). Beban glikemik dihitung berdasarkan nilai IG dan kadar karbohidrat per porsi sebagai berikut (Eleazu, 2016):

$$
B G=\frac{I G \times \text { Kadar Karbohidrat per porsi }}{100}
$$

\section{Analisis data}

Analisis data dilakukan dengan SPSS menggunakan ANOVA untuk melihat pengaruh jenis umbi terhadap perubahan kadar glukosa darah dan jika terdapat pengaruh dilanjutkan dengan uji Duncan untuk melihat perbedaannya $(\alpha=0.05)$. Uji t dilakukan untuk mengetahui ada perbedaan nilai IG pada penggunaan variasi umbi kue bingke. Data lainnya disajikan dalam bentuk rata-rata dengan standar deviasi (SD).

\section{HASIL DAN PEMBAHASAN}

\section{Karakteristik responden}

Karakteristik responden yang digunakan ditampilkan pada Gambar 2. Umur responden terdiri dari 8 orang 22 tahun dan sisanya 21 tahun dengan nilai rata-rata $22 \pm 0.42$. Indeks Masa Tubuh (IMT) responden masuk dalam katagori normal dengan rata-rata $21.16 \pm 1.82$ $\mathrm{kg} / \mathrm{m}^{2}$. Gula darah puasa atau DGP responden berada pada kisaran normal $(70-110 \mathrm{mg} / \mathrm{dl})$, yaitu antara $85 \pm 4.83 \mathrm{mg} / \mathrm{dl}$.

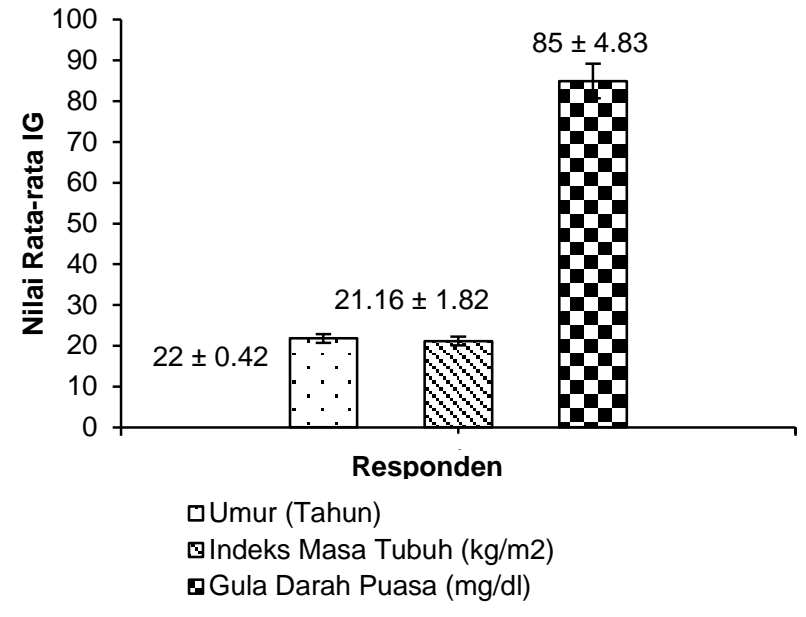

Gambar 2. Karakteristik responden pengukuran Indeks Glikemik (IG)

Pengukuran karakteristik responden dilakukan untuk mengurangi keragaman hasil penelitian. Terutama pengukuran kadar GDP puasa dilakukan untuk deteksi awal bahwa responden tidak sebagai penderita diabetes melitus (DM).

\section{Indeks glikemik (IG)}

Hasil pengukuran gula darah setelah mengonsumsi kue bingke ditampilkan pada grafik di Gambar 3. Grafik tersebut menunjukkan bahwa kue bingke variasi umbi memiliki peningkatan kadar glukosa darah yang lebih rendah pada menit ke-30 dengan tingkat kepercayaan 0.05. Peningkatan kadar klukosa darah pada menit ke-30 antara sampel glukosa berbeda nyata dengan kue bingke ubi jalar, dan begitu juga kue bingke kentang berbeda nyata dengan keduanya (glukosa dan ubi jalar). Peningkatan kadar glukosa menit ke-30 tertinggi hingga terendah adalah glukosa, kue bingke kentang, dan kue bingke ubi jalar. Oleh sebab itu kue bingke ubi jalar memiliki luas kurva yang berbeda nyata dengan glukosa, sedangkan kue bingke kentang memiliki luas kurva yang tidak berbeda nyata dengan keduanya (glukosa dan ubi jalar). Luas kurva secara berurutan dari standar glukosa, kue

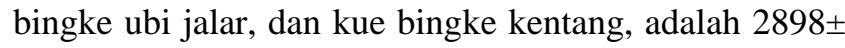
$681,2289 \pm 493$, dan 2689 \pm 658 .

Gambar 3 menggambarkan bahwa pada standar glukosa memiliki grafik yang lebih runcing dan kadar glukosa sudah berada di bawah kadar glukosa darah puasa (GDP) antara menit ke-90 dan 120 menit (sebelum menit ke-120). Kue bingke pada kedua variasi memiliki bentuk grafik yang lebih landai dengan pencapaian kadar glukosa darah dibawah GDP hingga menit ke-120. Data tersebut menunjukkan bahwa kue bingke variasi umbi memiliki waktu yang lebih lama untuk dicerna dan diduga dapat mempertahankan rasa kenyang hingga dua jam atau lebih lama dibandingkan dengan glukosa. Perasaan lapar dan inisiasi makan pada manusia berkolerasi pada saat kondisi glukosa darah rendah $(80 \mathrm{mg} / \mathrm{dl}$ atau lebih rendah) (Ciampolini dan Bianchi 2006). Kadar glukosa darah tersebut mendekati kadar glukosa darah puasa pada orang normal. 


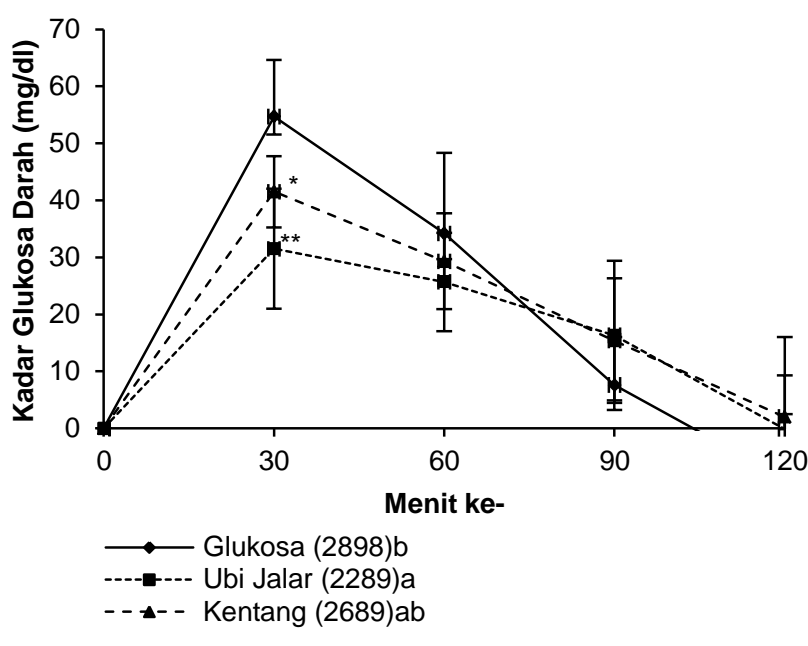

Keterangan: *Menunjukkan adanya perbedaan kadar glukosa darah yang nyata antar sampel dengan tingkat kepercayaan 0.05, dan angka yang diikuti huruf yang berbeda menunjukkan adanya perbedaan luas kurva yang nyata dengan tingkat kepercayaan 0.05

Gambar 3. Perubahan kadar glukosa setiap 30 hingga 120 menit setelah mengonsumsi kue bingke

Berdasarkan luas kurva pada Gambar 3 didapat nilai

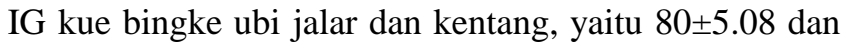
$93 \pm 4.93$ (Gambar 4). Nilai IG keduanya berbeda nyata pada tingkat kepercayaan 0.05 , yaitu IG kue bingke kentang lebih tinggi dibandingkan ubi jalar, akan tetapi keduanya masuk kedalam katagori yang sama, yaitu IG tinggi karena memiliki nilai IG diatas 70. Makanan dengan nilai IG diatas 70 masuk kedalam katagori tinggi (Powell et al. 2002). Oleh sebab itu perlunya pemantauan dalam segi jumlah konsumsi sekali makan agar tidak memiliki beban (BG) yang tinggi.

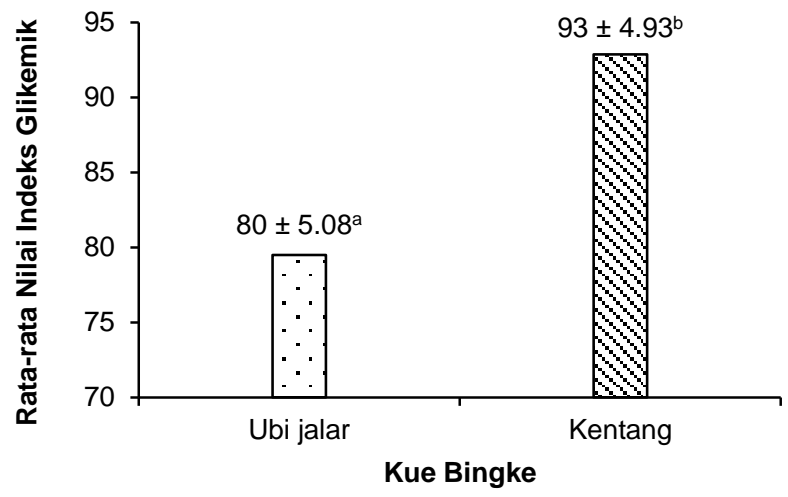

Keterangan: Angka yang diikuti huruf yang berbeda menunjukkan adanya perbedaan nyata dengan tingkat kepercayaan 0.05

Gambar 4. Nilai indeks glikemik (IG) kue bingke

Perbedaan nilai IG pada kue bingke ubi jalar dan kentang diduga karena perbedaan rasio amilosa dan amilopektin dari kedua umbi tersebut. Berbagai hasil penelitian menunjukkan bahwa bahan pangan dengan kandungan amilosa yang lebih tinggi memiliki nilai IG yang rendah (Arif et al. 2013). Kandungan amilosa ubi jalar umumnya dapat mencapai 30\% (Waramboi et al. 2011), sedangkan kentang 23\% (Sunarti 2002). Adanya amilosa memungkinkan membentuk pati resisten selama pengolahan. Pati resisten yang mungkin terbentuk salah satunya amilosa yang berikatan dengan lemak sehingga menjadi lebih sulit tercerna, sehingga memiliki nilai IG rendah. Amilosa dengan lemak dapat membentuk ikatan kompleks selama pengolahan menjadi pati resisten tipe 5 (Lee et al. 2020).

\section{Beban Glikemik (BG)}

Beban glikemik (BG) kue bingke ubi jalar dan kentang ditampilkan pada Tabel 2. Hasil menunjukkan bahwa kue bingke ubi jalar dan kentang memiliki BG rendah pada porsi konsumsi $60 \mathrm{~g}$ dan $120 \mathrm{~g}$. Porsi $180 \mathrm{~g}$ juga masih menunjukkan katagori BG yang sama, yaitu sedang untuk keduanya. Akan tetapi pada porsi $240 \mathrm{~g}$ kue bingke kentang masuk dalam katagori BG tinggi, sedangkan kue bingke ubi jalar BG sedang. Berdasarkan hal tersebut porsi ideal dengan acuan $\mathrm{BG}$ rendah pada kue bingke ubi jalar dan kentang adalah $120 \mathrm{~g}$ atau dua potong.

Tabel 2. Beban glikemik kue bingke pada berbagai porsi

\begin{tabular}{ccccc}
\hline Kue & \multicolumn{4}{c}{ Beban Glikemik (BG)/Katagori } \\
\cline { 2 - 5 } Bingke & $\mathbf{6 0 ~ g}$ & $\mathbf{1 2 0} \mathbf{g}$ & $\mathbf{1 8 0} \mathbf{~ g}$ & $\mathbf{2 4 0} \mathbf{~ g}$ \\
\hline Ubi jalar & 4 & 8 & 12 & 16 \\
& (Rendah) & (Rendah) & (Sedang) & (Sedang) \\
Kentang & 5 & 10 & 15 & 20 \\
& (Rendah) & (Rendah) & (Sedang) & (Tinggi) \\
\hline
\end{tabular}

Konsumsi dua potong kue bingke memberikan estimasi sumbangan energi sebesar 297 kkal untuk kue bingke ubi jalar dan 303 kkal untuk kue bingke kentang. Jumlah energi tersebut menyumbang sekitar 14\% kebutuhan energi berdasarkan angka kecukupan gizi (AKG) $2150 \mathrm{kkal}$.

\section{Konsumsi kue bingke}

Data konsumsi kue bingke variasi umbi yang disukai dan jumlah sekali makan ditampilkan pada Gambar 5. Hasil menunjukkan selain original, kue bingke variasi umbi yang paling sering dikonsumsi adalah ubi jalar. Sedangkan untuk porsi sekali makan kue bingke persentase tertinggi adalah sebanyak dua potong (120 g). Hasil tersebut menunjukkan bahwa telah ada ketepatan antara kebiasaan konsumsi secara umum dalam segi jumlah porsi sekali makan kue bingke yang memiliki nilai BG rendah.

\section{KESIMPULAN}

Kue bingke variasi umbi memiliki katagori nilai indeks glikemik (IG) tinggi, akan tetapi memiliki beban glikemik (BG) rendah pada porsi konsumsi $120 \mathrm{~g}$ (2 potong). Jumlah konsumsi tersebut dapat menyumbangkan energi sekitar 297-303 kkal atau memenuhi 14\% kebutuhan gizi (AKG $2150 \mathrm{kkal}$ ). Jumlah porsi yang umum dikonsumsi telah memenuhi jumlah porsi yang memiliki BG rendah. 


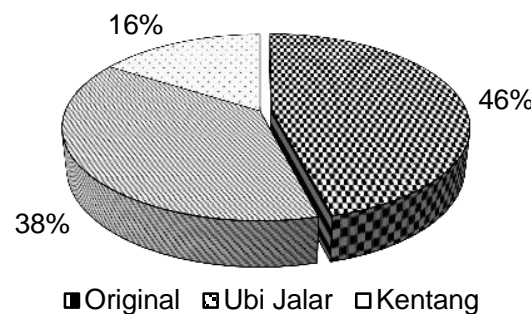

A

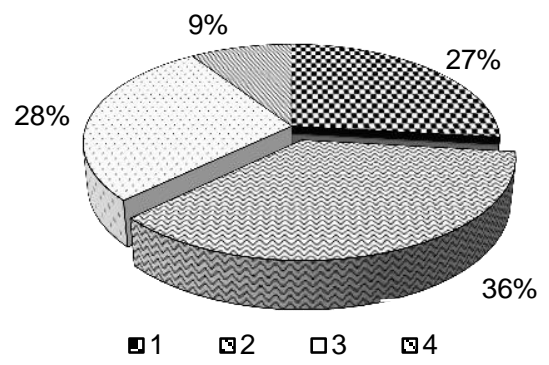

Gambar 5. Jenis variasi kue bingke yang disukai (a), dan jumlah potongan sekali makan yang biasa dikonsumsi (b)

\section{DAFTAR PUSTAKA}

Agustin LS, Kendall CWC, Jenkis DJA, Willet WC, Astrup A, Barclay AW, Bjorck I, Brand-Miller JC, Brighenti F, Buyken AE, Ceriello A, La Vecchia C, Livesey G, Liu S, Riccardi G, Rizkalla SW, Sievenpiper JL, Trichopoulou A, Wolever TMS, BaerSinnott S, Poli A. 2015. Glycemic index, glycemic load and glycemic response: An International Scientific Consensus Summit from the International Carbohydrate Quality Consortium (ICQC). Nutr, Metabolism \& Cardiovascular Disease 25: 795-815. DOI: 10.1016/j.numecd. 2015.05.005.

Arif AB, Boediyanto A, Heorudin. 2013. Nilai indeks glikemik produk pangan dan faktor-faktor yang mempengaruhi. J Litbang Pert 32(3): 91-99.

[BPOM] Badan Pengawas Obat dan Makanan. 2011. Pengawasan Klaim dalam Label dan Iklan Pangan Olahan, Peraturan Kepala Badan Pengawas Obat dan Makanan Republik Indonesia, Jakarta: Badan Pengawasan Obat dan Makanan.

Chiasson JL, Josse RG, Gomis R, Hanefeld M, Karasik A, Laakso M. 2002. Acarbose for prevention of type 2 diabetes mellitus: the STOP-NIDDM randomised trial. The Lancet 359(9323): 2072-2077. DOI: 10.1016/S0140-6736(02)08905-5.

Ciampolini M, Bianchi R. 2006. Training to estimate blood glucose and to form associations with initial hunger. Nutr Metab 3(42): 1-11. DOI: 10.1186/ 1743-7075-3-42.

Eleazu CO. 2016. The concept of low glycemic index and glycemic load foods as panacea for type 2 diabetes mellitus; prospects, challenges and solu- tions. Afr Health Sci 16(2): 468-479. DOI: 10.4314/ ahs.v16i2.15.

Fatema K, Sumi N, Rahman F, Kobura K, Ali L. 2011. Glycemic Index determination of vegetable and fruits in healthy Bangladeshi subjects. Mal J Nutr 17(3): 393 - 399.

Ilmannafian AG, Lestari E, Halimah. 2018. Pemanfaatan tepung garut sebagai substitusi tepung terigu dalam pembuatan kue bingka. Teknologi Agro-Industri 5(2): 141-151. DOI: 10.34128/jtai.v5i2.80.

Lee HS, Kim KH, Park SH, Hur SW, Auh JH. 2020. Amylose-Lipid complex as a fat replacement in the preparation of low-fat white pan bread. Foods 9(2): 1-12. DOI: 10.3390/foods9020194.

Lestari E, Kipitah M, Apifah. 2017. Karakteristik tepung kacang hijau dan optimasi penambahan tepung kacang hijau sebagai pengganti tepung terigu dalam pembuatan kue bingka. J Teknol Agro-Ind 4(1): 2034. DOI: 10.34128/jtai.v4i1.45.

Panjaitan C, Yanuarti, Khulyatun T, Nundya GI, Lingga L, Haryanto MM, Herfarina. 2014. Panduan Penerapan Cara Produksi Pangan yang Baik (SPPB) kue bingke. 1 Penyunt. Pontianak: Balai Besar POM.

Pawlak DB, Kushner JA, Ludwig DS. 2004. Effects of dietary glycaemic index on adiposity, glucose homoeostasis, and plasma lipids in animals. The Lancet 364(9436): 778-785. DOI: 10.1016/S01406736(04)16937-7.

Powell KF, Holt SH, Miller JCB. 2002. International table glycemic index dan glycemic load values. $\mathrm{Am}$ J Clin Nurt 76(1): 5-56. DOI: 10.1093/ajen/76.1.5.

Putri HL, Syarif W. 2019. Inventarisasi jenis dan resep kue tradisional di Kabupaten Empat Lawang Provinsi Sumatera Selatan. J Kapita Selekta Geografi 2(2): 124-137.

Putri M, Dewi YSK, Lestari OA. 2019. Analisis kandungan gizi dan penilaian organoleptik kue bingke umbi-umbian. J Sains Mahasiswa Pertanian 8(1): 16.

Sunarti TC. 2002. Study on outer chains from amylopectin between immobilized and free debranching enzymes. J Appl Glycosci 48(1): 1-10. DOI: 10. 5458/jag.48.1.

Thomas DE, Elliott EJ. 2010. The use of low-glycemic index diets in diabetes control. Br J Nutr 104(6): 797-802. DOI: 10.1017/S0007114510001534.

Waramboi JG, Dennien S, Gidley JM, Sopade AP. 2011. Characterisation of sweetpotato from Papua New Guinea and Australia: Physicochemical, pasting and gelatinization properties. Food Chem 126(4): 17591770. DOI: 10.1016/j.foodchem.2010.12.077.

JMP-11-20-15-Naskah diterima untuk ditelaah pada 29 Agustus 2020. Revisi makalah disetujui untuk dipublikasi pada 19 Oktober 2020. Versi Online: http://journal.ipb.ac.id/index.php/jmpi 